\title{
MUSLIM TRAVELLERS' PERCEPTION ON QUALITY OF SERVICE BY UMRAH AND HAJJ TRAVEL AGENCIES IN MALAYSIA
}

\author{
AINATUN NABIHAH MOHD SHUKRI, KALSITINOOR SET*, AZIZUL YADI YAAKOP
}

School of Maritime Business and Management, Universiti Malaysia Terengganu, 20130 Kuala Nerus, Terengganu, Malaysia

*Corresponding author: kalsitinoor@umt.edu.my

\begin{abstract}
Millions of Muslims from all over the world perform Umrah and Hajj every year. There were 250,000 pilgrims from Malaysia in 2017, and the number is expected to grow by 20 percent in 2018. This projected increase will create a huge demand for Umrah and Hajj travel agencies' services in Malaysia. At present, there are 328 Umrah and Hajj travel agencies registered under Malaysia's Ministry of Tourism and Culture (MOTAC). However, the supposedly bright outlook maybe marred by undesirable consequences. Along with the increase in the number of Umrah and Hajj travel agencies, there also tends to be an increase in fraud Umrah packages offered by fake agents in Malaysia. Such incidents will cause sadness and anger in the victims and other involved parties. Umrah package fraud involving fake agents in Malaysia has attracted the attention of many including the public, the government, the private sector, even the media. Nevertheless, studies on correlation between Muslim travellers' perception of the quality of service by Umrah travel agencies and their decision to purchase the Umrah package are scarce in Malaysia. Hence, this study investigated Muslim travellers' perception of Umrah and Hajj travel agencies' service quality and its influence on their decision to purchase the Umrah package, in an attempt to discover why some Muslim travellers fell into fake agents' trap in Malaysia. A total of 319 Muslim respondents completed the questionnaire on service quality perception, specifically service quality elements and loyalty. The data obtained was examined using SPSS version 25 for descriptive and regression analysis. Umrah and Hajj travel agencies as well as relevant government agencies could use the findings of the study to assist with formulating plans and policies to improve the quality of service by Umrah and Hajj industry players and awareness among Muslim travellers on the importance of being able to identify bogus agencies. The limitations, implications and suggestions for future research are also discussed.
\end{abstract}

Keywords: Umrah and Hajj travel agency, service quality, muslim travellers, Ministry of Tourism and Culture (MOTAC), fraudulent Umrah packages, fake agents.

\section{Introduction}

Customer loyalty is very important in the context of Umrah and Hajj package business as it is one way to avoid falling for fraud package offered by unfamiliar fake agents. Over time, the number of tour package providers has been growing fast. At present, there are 66 registered Umrah tour package providers under the monitoring of Umrah Monitoring Council (MKSU). When there are too many choices of tour package providers, it is more likely for the customers to fall for fraud packages. The increasing number of Umrah fraud cases every year has become a major concern among the Malaysian Muslims.

There have been more than three thousand Malaysian Muslims falling for Umrah fraud packages since 2012. More than three thousand cases of Umrah fraud packages had been filed with the tribunal, involving at least RM20 million. On top of that, 216 cases had been filed with the police, involving more than RM8 million. Following court trials, Umrah licences for
11 companies had been revoked, with more than RM 200,000 collected in fines (Buang, 2017).

Therefore, it can be seen that fraud Umrah tour package is not a new phenomenon in Malaysia. Every year, similar cases keep occurring, making the Muslims feel anxious when considering performing Umrah. However, this issue has not been widely researched. Hence, this study investigated the factors that may lead to the customer loyalty, focusing specifically on Umrah tour package providers.

\section{Service Quality (SERVQUAL) Model}

SERVQUAL model is not a new tool in the world of research. Vasumathi \& Subashini (2015) state that SERVQUAL model may help in influencing customer loyalty. If the customers are satisfied with the services delivered by tour package providers that will lead to customer loyalty. This study chose to use four dimensions of SERVQUAL model: tangible, reliability, responsiveness, empathy and assurance. 


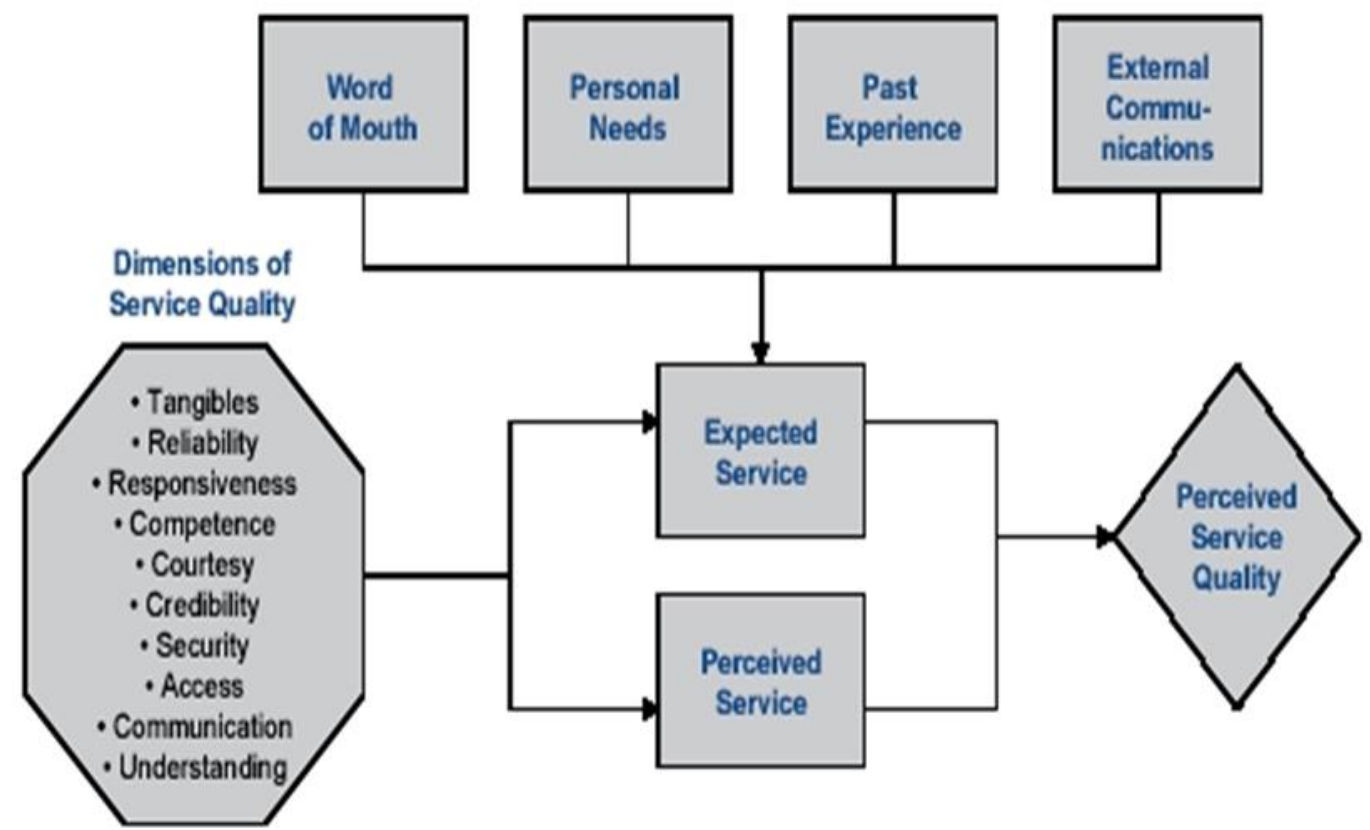

Figure 1: SERVQUAL MODEL

\section{Tangible}

The Tangible dimension is defined as the look of the staff, actual facilities, tools and communication particulars (Roslan, Wahab \& Abdullah, 2015). In addition, Oxford dictionary states the meaning of tangible as 'a thing that is perceptible by touch'. Thus, the researcher suggests the following hypothesis:

Hypothesis 1 (H1): The tangible of tour package providers significantly predicts loyalty of Muslim travellers.

\section{Reliability}

The Reliability dimension is defined as the competence to carry out the agreed service responsibly and precisely, which in turns will lead to the loyalty of the clients towards the company (Peprah \& Atarah, 2014). Thus, the researcher suggests the following hypothesis:

Hypothesis $2(\mathrm{H} 2)$ : The reliability of tour package providers significantly predicts loyalty of Muslim travellers

\section{Responsiveness}

The Responsiveness dimension is defined as the readiness to assist customers and to give immediate service (Roslan et al., 2015). Oxford dictionary states the meaning of responsiveness as 'the quality of reacting quickly and positively'. Thus, the researcher suggests the following hypothesis:

Hypothesis 3 (H3): The responsiveness of tour package providers significantly predicts loyalty of Muslim travellers.

\section{Assurance}

The Assurance dimension is defined as the wisdom and politeness of workers and their capability to impart firm and strong belief (Roslan et al., 2015). Thus, the researcher suggests hypothesis the following:

Hypothesis 4 (H4): The assurance of tour package providers significantly predicts loyalty of Muslim travellers.

\section{Empathy}

Oxford dictionary states the meaning of empathy as 'the ability to understand and share the feelings of another'. The element of empathy is not important for first-time customers, but it maybe useful to influence repeat customers. For instance, a customer who is satisfied with the service of one company decides to try another for a change but returns to the earlier company and complains about the new company. This is a timely opportunity to provide empathy to the customer to maintain the loyalty. Thus, the researcher suggests the following hypothesis: Hypothesis 5 (H5): The empathy of tour package providers significantly predicts loyalty of Muslim travellers.

\section{Loyalty}

As cited in Eid (2013), customer loyalty can be classified into two: "behavioural loyalty and attitudinal loyalty" (Dick \& Basu, 1994; Nam et al., 2011). Eid (2013) also cited that "Attitudinal loyalty refers to the psychological commitment that a consumer makes in the purchase act, such as intentions to purchase and intentions to recommend without necessarily taking the actual repeat purchase behavior into account" (Jacoby, 1971; Jarvis \& Wilcox, 1976). 


\section{Materials and Methods}

This study involved respondents living in Peninsular Malaysia and due to their fragmented nature, the questionnaire was administered to the respondents in person and via the online approach through Facebook and WhatsApp group for eight months. The respondents were selected based on the following criteria: they must be Muslim travellers and had performed Umrah through Umrah travel agencies. In this study, snowball sampling was chosen due to the unknown population. Awang (2010) has provided guidelines for snowball sampling. First, the researcher selects one respondent who meets the criteria. Next, the researcher asks the first respondent to find relatives and friends who also meet the criteria. The same method is used for subsequent respondents until enough sample size is obtained.

In an article on a website titled 'Sample Size Determination Using Krejcie and Morgan Table' (2016) it was stated that there are several ways to determine a sample size. Using Patrick' formula for unknown population (2015), the formula below was used to determine the sample size as it showed the representative number of respondents (Godden, 2014). The sample size needed for this study was 384. At the beginning, a questionnaire was distributed to 400 respondents either in person or through online approach. Out of the 400, only 319 respondents returned usable responses, giving an overall response rate of 80 percent. According to Mugenda and Mugenda (as cited in PATRICK, 2015), 50 percent response rate is considered as acceptable to conduct a study, 60 percent is considered as good and 70 percent is considered as great.

\section{Results and Discussion}

Of the 319 respondents, there were more females (73\%) than males (27\%). Most respondents were in the age range of 22 to 37 years old at 35 percent, while others were between 17 and 21 years old, which were at 13 percent. In terms of type of jobs, most of the respondents were private sector employees (frequency of 91), followed by students (frequency of 78), government sector employees (frequency of 52), pensioners (frequency of 39) and unemployed (frequency of 35). The respondents' highest education level was Bachelor level $(40 \%)$, followed by SPM \& STPM level at 32 percent, then Diploma level followed by Master's level, which were 19 percent and 7 percent, respectively. Only 2 percent were $\mathrm{PhD}$ holders. As for the yearly income, the majority of respondents (54\%) made less than RM10, 000 per year, while $5 \%$ made more than RM100, 000 per year.

Table 1 shows that (constant), tangible, responsiveness, assurance and empathy were significantly related to the loyalty at $\mathrm{P}<0.01$ and $\mathrm{P}<0.05$ respectively, while reliability was not significantly related to the loyalty.

Table 1: Research Hypothesis Result (RO1)

\begin{tabular}{|c|c|c|c|c|}
\hline No. & & Multiple Regression Analysis & Statistical Test & P-value \\
\hline 1 & $\mathrm{H} 1$ & $\begin{array}{l}\text { The tangibles of tour package provider significantly predict } \\
\text { loyalty of Muslim travellers. }\end{array}$ & Accepted & 0.008 \\
\hline 2 & $\mathrm{H} 2$ & $\begin{array}{l}\text { The reliability of tour package provider significantly predicts } \\
\text { loyalty of Muslim travellers. }\end{array}$ & Rejected & 0.338 \\
\hline 3 & $\mathrm{H} 3$ & $\begin{array}{l}\text { The responsiveness of tour package provider significantly } \\
\text { predicts loyalty of Muslim travellers. }\end{array}$ & Accepted & 0.000 \\
\hline 4 & $\mathrm{H} 4$ & $\begin{array}{l}\text { The assurance of tour package provider significantly predicts } \\
\text { loyalty of Muslim travellers. }\end{array}$ & Accepted & 0.000 \\
\hline 5 & $\mathrm{H} 5$ & $\begin{array}{l}\text { The empathy of tour package provider significantly predicts } \\
\text { loyalty of Muslim travellers. }\end{array}$ & Accepted & 0.006 \\
\hline
\end{tabular}

Source: Data derived from survey 


\section{Conclusion}

This study examined Muslim travellers' perception on the quality of service by Umrah and Hajj travel agencies in Malaysia. Overall, Muslim travellers did not consider reliability of the Umrah tour provider as one of the criteria for loyalty towards the agency. This is alarming, which explains the increasing fraud cases of Umrah tour packages in Malaysia. Genuine Umrah travel agencies must continue to provide better customer service in order to secure the loyalty of Muslim travellers. Having a clearer understanding of the relationship between service quality and customer loyalty can help ensure a better solution regarding the issues of Umrah fraud.

Meanwhile, Muslim travellers should make a confirmation regarding the status of the Umrah tour agencies with legal organizations such as MOTAC and MKSU before deciding to purchase the Umrah package. Besides that, they also must study about the company before deciding to choose it. Mass media such as television and radio also should play their roles in promoting relevant campaigns to make sure the citizens are aware about this situation.

On top of that, the government must create more awareness of the citizens about this issue by creating programmes for the elderly community especially at remote areas who are highly susceptible to become victims of the scams. Disseminating information about the blacklisted Umrah tour package providers to the public is also recommended. Companies Commission of Malaysia, the authorized agency for company registration in Malaysia is also able to help customers avoid being deceived by the same blacklisted Umrah tour package providers. Awareness programmes should be included by the mosque committees as well in order to ensure the participation among local community in creating awareness among villagers. Furthermore, the private sector also has to play a significant role, which is working together with the government sector. This may be one of the solutions to help prevent the number of the fraud Umrah cases from increasing.

\section{References}

Amissah, E. F. (2013). Tourist satisfaction with hotel services in Cape Coast and Elmina, Ghana. American Journal of Tourism Management, 2 (A), 26-33.

Awang, Z. H. (2010). Research Methodology for Business and Social Science. Pusat Penerbitan Universiti, Universiti Teknologi MARA.

Benjamin, N. (2014, October 2). Umrah package fraud on the rise. Retrieve from http://www.thestar.com.my/news/community/2014/ 10/02/umrah-package-fraud-on-the-rise-pilgrimsshould-ensure-tour-operators-are-licensed/

Business Dictionary (2017). Service Quality Definition.

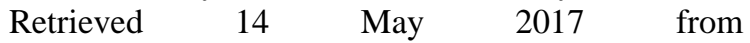
http://www.businessdictionary.com/definition/servic equality.html

Buang, S. (2017, January 5). Increase fraud packages. Retrieve from http://www.nst.com.my/news/2017/01/201965/incre ase-fraud-packages

Collier J.E., Bienstock C.C. (2015) A Conceptual Framework for Measuring E-Service Quality. In: Spotts H. (eds) Creating and Delivering Value in Marketing. Developments in Marketing Science: Proceedings of the Academy of Marketing Science. Springer, Cham

Das, K. R., \& Imon, A. H. M. R. (2016). A brief review of tests for normality. American Journal of Theoretical and Applied Statistics, 5(1), 5-12.

Eid, R. (2013). Integrating Muslim Customer Perceived Value, Satisfaction, Loyalty and Retention in the Tourism Industry: An empirical study. International Journal of Tourism Research, 17(3), 249-260. doi:10.1002/jtr.1982

Florian, L. (2015). Inclusive Pedagogy: A transformative approach to individual differences but can it help reduce educational inequalities. Scottish educational review, 47(1), 5-14.

George, D., \& Mallery, P. (2003). SPSS for Windows step by step: A simple guide and reference 11.0 update ( $4^{\text {th }}$ ed.). Boston: Allyn \& Bacon

Ghotbabadi, A. R., Feiz, S., \& Baharun, R. (2015). Service Quality Measurements: A Review. International Journal of Academic Research in Business and Social Sciences, 5(2). doi:10.6007/ijarbss/v5-i2/1484

Google Forms - create and analyze surveys, for free. (n.d.). Retrieved April 18, 2017, from https://www.google.com/forms/about/

Hassan, S. H., Maghsoudi, A., \& Nasir, N. I. (2016). A conceptual model of perceived value and consumer satisfaction: a survey of Muslim travellers' loyalty on Umrah tour packages. International Journal of Islamic Marketing and Branding, 1(3), 215. doi:10.1504/ijimb.2016.075851 
Horner, S., \& Swarbrooke, J. (2016). Consumer behaviour in tourism. Abingdon, Oxon: Routledge, is an imprint of the Taylor \& Francis Group, an Informa Business.

Idris, A. (n.d.). Senarai Syarikat Mempunyai Lesen Khas Umrah Sehingga 22 November 2017. Retrieved December 14, 2017, from http://umrahmksu.motac.gov.my/lesen-khasumrah/lku

Kang'ethe, S. M., \& Wotshela, N. (2015). Empirical Exploration of Perceptions on Attitudes Pertaining to Foreignness and Diversity in Tertiary Institutions in South Africa Using the Staffs' and Students' Lenses: The Case of the University of Fort Hare. International Journal of Educational Sciences, 10(3), 451-462.

Kudo, Y., Nakagawa, A., Tamura, N., Kato, N., Williams, A., Aida, N., \& Mimura, M. (2016). The reliability and validity of the Japanese version of the Temperament and Personality Questionnaire for patients with non-melancholic depression. Journal of Affective Disorders, 198, 237-241. doi:10.1016/j.jad.2016.03.046

Kline, p. (2000). The handbook of psychological testing ( $2^{\text {nd }}$ ed.). pp.13. London:Routledge

Kotler, P. (1988), Marketing Management: Analysis, Planning and Control, Prentice - Hall, Englewood Cliffs, NJ.

Oktora, K., Using SERVQUAL Model. Procedia - Social and Behavioral Sciences, 172, 457-462. doi:10.1016/j.sbspro.2015.01.380

Olsen, D.H. (Eds.): Tourism, Religion and Spiritual Journeys, Routledge, London.

Oxford Dictionaries - Dictionary, Thesaurus, \& Grammar. (n.d.). Retrieved May 14, 2017, from https://en.oxforddictionaries.com/

Parasuraman, A., Zeithaml, V. A., \& Berry, L. L. (1988). Servqual: A Multiple-Item Scale for Measuring Consumer Perceptions of service quality Journal of Retailing, 64(1), 12-40.

Pallant, J. (2013). SPSS survival manual. McGraw-Hill Education (UK).

Patrick, E. R. O. (2015). Effect of Agency Banking Services on Customer Satisfaction: A Case Of Kenya Commercial Bank Agent System In Ongata Rongai, Kenya.
Polit, D. F., \& Hungler, B. P. (1997). Essentials of nursing research: Methods, appraisals and utilisation. 4th edition. Philadelphia: Lippincott-Raven Publishers.

Razali, N. M., \& Wah, Y. B. (2011). Power comparisons of shapiro-wilk, kolmogorov-smirnov, lilliefors and anderson-darling tests. Journal of statistical modeling and analytics, 2(1), 21-33.

Roslan, N. A., Wahab, E., \& Abdullah, N. H. (2015). Service Quality: A Case Study of Logistics Sector in Iskandar Malaysia World Factbook. (2017, January 19). Retrieved May 13, 2017, from https://www.cia.gov/library/publications/resources/t he-world-factbook/geos/print_my.html

Sample Size Determination Using Krejcie and Morgan Table. (2016, May 01). Retrieved December 09, 2017, from http://www.kenpro.org/sample-sizedetermination-using-krejcie-and-morgan-table/

SERVQUAL model, quality analysis of services - PDCA Home (en). (n.d.). Retrieved May 02, 2017, from http://pdcahome.com/english/191/servqual-modelquality-analysis-of-services/

Service Quality. BusinessDictionary.com. Retrieved May 10, 2017, from Business Dictionary.com website: http://www.businessdictionary.com/definition/servic e-quality.html

Stauber, D. (2016, November 15). What's New in IBM SPSS Statistics 24. Retrieved April 18, 2017, from https://developer.ibm.com/predictiveanalytics/2016/ 03/15/whats-new-in-ibm-spss-statistics-24/

The World Factbook. (2017, January 19). Retrieved May 13, 2017, from https://www.cia.gov/library/publications/resources/t he-world-factbook/geos/print_my.html

Vasumathi, A., \& Subashini, R. (2015). The influence of SERVQUAL dimensions on customer loyalty in banking sector, India - an empirical study. International Journal of Services and Operations Management, 21(3), 370. doi:10.1504/ijsom.2015.069656

Verses including the word Travel. (n.d.). Retrieved April 16, 2017, from http://www.quranindex.net/kelime.php?id=8809

Yaacob, M. R. (2013). SPSS Statistic 20 for Business and Social Science Students. 
Yarimoglu, E. K. (2014). A review on dimensions of service quality models. Journal of Marketing Management, 2(2), 79-93.

Yatim, N. (2016, February 5). Sasar 9,000 Jemaah Sepanjang 2016. Retrieved from http://www.sinarharian.com.my/mobile/edisi/tereng ganu/sasar-9-000-jemaah-sepanjang-2016-1.481899

Ying, T. P. (2015, September 22). Tourism Ministry revokes companies' licenses for fraud Umrah and Haj packages. Retrieved May 14, 2017, from http://www.nst.com.my/news/2015/09/tourismministry-revokes-companies\%E2\%80\%99-licensesfraud-umrah-and-haj-packages

Yunus, N., Bojei, J., \& Rashid, W. (2013). Service Quality towards Customer Loyalty in Malaysia"es Domestic Low Cost Airline Services. International Journal of $e$-Education, e-Business, e-Management and $e$ Learning. doi:10.7763/ijeeee.2013.v3.253 